\title{
Asesmen ECG-Apnea Satu Sadapan untuk Peningkatan Akurasi Klasifikasi Gangguan Tidur Berdasarkan AdaBoost
}

\section{(Single Lead ECG-Apnea Recordings Assessment for Improved Accuracy in Classification of Sleep Disorder based on AdaBoost)}

\author{
Iman Fahruzi ${ }^{1,3}$, I Ketut Eddy Purnama ${ }^{1,2}$, Mauridhi Hery Purnomo ${ }^{1,2}$
}

\begin{abstract}
Sleep disorder is a disturbed breathing flow (collapse) during sleep. The symptoms are generally undiagnosed and untreated properly so that repeated respiratory interruptions have the potential for severe sleep disorders. Electrocardiogram (ECG) recordings are practical tools used to examine the existence of sleep disorders in the heart rhythm. The ECG represents heart electrical activity in the form of $P, Q R S$, and $T$ waves. The number of ECG sensors is uncomfortable for the patient to record the data, increasing the recording complexity, slowing the computation, causing misinterpretation and loss of clinical information. Therefore, an early warning system is needed as a medical aid that can be diagnosed using single-lead ECG. In conducting this study, the system consists of five stages, which include the acquisition of ECG records, pre-processing, extraction of features, selection of features, and the classification process. ECG-record feature sets consist of time-domain, frequency-domain, and non-linear analysis. The AdaBoost method confirms that the model had the highest performance than the SVM, k-NN and NN. The results of the experiments thus measure the outperformed of method performance and achieved $\mathbf{9 0 . 1 \%}$ classification accuracy for the AdaBoost classification method. Moreover, the F1 score, precision, recall, sensitivity, and specificity was reported as $90.1 \%, 90.3 \%, 90.1 \%, 86.9 \%$, and $93.3 \%$, respectively.
\end{abstract}

Intisari-Gangguan tidur adalah terganggunya aliran pernapasan (kolaps) yang berulang saat tidur. Gangguan tidur umumnya tidak terdiagnosis dan tidak tertangani dengan baik sehingga terjadi interupsi berulang pada saluran pernapasan. Kondisi tersebut berpotensi menyebabkan penderita mengalami gangguan tidur yang serius. Salah satu alat bantu yang digunakan untuk menganalisis adanya gangguan tidur pada ritme jantung adalah melalui rekaman electrocardiogram (ECG). ECG merupakan suatu grafik yang merepresentasikan aktivitas listrik pada jantung berupa gelombang $P$, gelombang QRS, dan gelombang T. Banyaknya sensor untuk merekam ECG menyebabkan ketidaknyamanan pasien saat perekaman data,

${ }^{1}$ Departemen Teknik Elektro, Fakultas Teknologi Elektro dan Informatika Cerdas, Institut Teknologi Sepuluh Nopember, Jl. Raya ITS, Sukolilo, Surabaya 60111, INDONESIA (tlp/fax.: 0315947302; email: imanfahruzi.17071@mhs.ee.its.ac.id; ketut@ee.its.ac.id; hery@ee.its.ac.id)

${ }^{2}$ Departemen Teknik Komputer, Fakultas Teknologi Elektro dan Informatika Cerdas, Institut Teknologi Sepuluh Nopember, Jl. Raya ITS, Sukolilo, Surabaya 60111, INDONESIA (tlp/fax.: 0315922936; email:ketut@ee.its.ac.id; hery@ee.its.ac.id)

3 Program Studi Teknik Elektronika, Jurusan Teknik Elektro, Politeknik Negeri Batam, Jl. Ahmad Yani, Batam Center, Batam 29461, INDONESIA (tlp/fax.: 0778-463620; email: iman@polibatam.ac.id) menyebabkan kompleksitas rekaman, lambatnya komputasi, kesalahan dalam interpretasi, dan kehilangan informasi klinis. Oleh karena itu, dibutuhkan suatu sistem peringatan dini sebagai alat bantu medis yang mampu mendiagnosis rekaman ECG menggunakan satu sadapan. Sistem didesain menjadi lima tahapan, yaitu akuisisi rekaman ECG, praproses, ekstraksi fitur, seleksi fitur, dan proses klasifikasi. Fitur set yang diperoleh dari rekaman ECG berupa variabel-variabel yang diperoleh dari domain waktu, domain frekuensi, dan analisis nonlinear. Pengujian menunjukkan metode AdaBoost memiliki nilai kinerja paling tinggi dibandingkan dengan SVM, $k-N N$, dan NN. Metode AdaBoost secara berurutan memiliki kinerja classification accuracy, F1 score, precision, recall, sensitivity, dan specificity sebesar $90,1 \%, 90,1 \%, 90,3 \%, 90,1 \%, 86,9 \%$, dan $93,3 \%$.

Kata Kunci- Rekaman ECG, Gangguan Tidur, SVM, AdaBoost, Mesin Pembelajaran.

\section{Pendahuluan}

Perkembangan teknologi dan gaya hidup menuntut setiap orang untuk bekerja keras dan tanpa batas waktu. Kesibukan menjadikan setiap orang lalai dalam menjaga tubuh tetap sehat. Dampak jangka panjangnya adalah potensi mengalami berbagai penyakit, salah satunya gangguan tidur. Kesulitan tidur terkadang membuat frustrasi dan melelahkan. Kondisi ini menyebabkan kualitas hidup terganggu dan dapat berakibat pada kematian jika tidak ditangani secara serius. Penelitian menyebutkan bahwa gejala gangguan tidur dapat menyebabkan kenaikan berat badan, kecelakaan kerja, kecelakaan saat berkendara, penurunan daya ingat, depresi, stress, dan gangguan jantung serius yang berakibat pada kematian [1]. Pada beberapa kasus, gangguan tidur juga berpengaruh pada tekanan darah yang tinggi, strok pada otak, dan gangguan pada ritme jantung [2]. Gangguan tidur ada beberapa jenis, di antaranya insomnia, sleep apnea (SA), restless legs syndrome, dan narkolepsi [3], [4]. Gangguan tidur yang umum dikenal dan banyak dialami sebagian orang adalah SA. Berdasarkan diagnosisnya, penyakit SA dikategorikan menjadi tiga, yaitu Obstructive Sleep Apnea (OSA), Central Sleep Apnea (CSA), dan Mixed Sleep Apnea (MSA). Kategori-kategori SA ini dapat diketahui dengan memperhatikan frekuensi kemunculan dari Apnea/Hypopnea Index (AHI) per jam. Kriteria skor AHI berdasarkan standar adalah klasifikasi AHI $<5$ diindikasikan sebagai kondisi OSA normal, AHI antara 5-14 sebagai OSA kategori ringan, AHI antara 15-30 sebagai OSA kategori sedang, dan AHI > 30 diklasifikasikan sebagai OSA dengan kategori parah [5]. Prevalensi OSA diperkirakan sebesar 9\%$24 \%$ dari jumlah populasi dan sebanyak $90 \%$ tidak terdiagnosis 
[6]. Tidak teridentifikasinya penderita OSA dalam jangka panjang akan berdampak pada risiko implikasi penyakit serius.

Polysomnography (PSG) merupakan metode standar bagi tenaga medis untuk merekam aktivitas listrik jantung pada bagian tubuh. PSG umumnya menggunakan lebih dari dua belas sensor [7], di antaranya sensor electrocardiogram (ECG) untuk merekam aktivitas listrik pada bagian jantung [8], [9], sensor electroencephalogram (EEG) untuk merekam aktivitas listrik pada bagian otak [10]-[12], dan sensor yang merekam kandungan SpO2 pada darah [13]. Penggunaan PSG pada dasarnya memiliki beberapa kekurangan, di antaranya kompleksitas dan kerumitan saat perekaman data karena banyaknya sensor yang digunakan. Ini menyebabkan komputasi yang lama, biaya mahal, kebutuhan akan keahlian dan keterampilan khusus, serta ketidaknyamanan pasien saat perekaman data karena faktor lingkungan pada kondisi tertentu. Kekurangan tersebut pada akhirnya berdampak pada data yang hendak dianalisis, bahkan memungkinkan terjadinya kesalahan diagnosis karena adanya potensi kehilangan atau kerusakan informasi klinis.

Pada beberapa penelitian, secara garis besar ada lima tahapan untuk mendeteksi gangguan tidur. Tahap akuisisi data bertujuan untuk mendapatkan data pengujian yang sesuai dengan kebutuhan penelitian. Data ECG umumnya berdurasi 7 8 jam untuk setiap pasien. Durasi yang lama akan sangat sulit dianalisis karena kompleksitas rekaman, banyaknya derau, dan adanya kemungkinan indikasi penyakit jantung lainnya. Oleh karena itu, diperlukan proses pemotongan data ECG untuk mendapatkan hasil analisis yang lebih akurat. Proses pemotongan ini dilakukan berdasarkan hasil evaluasi tenaga medis dari rumah sakit yang mampu menunjukkan adanya hubungan antara rekaman ECG dan pola sinyal untuk pasien yang mengalami gangguan tidur. Salah satu penelitian menggunakan rekaman ECG dengan durasi 30 detik dan 1 menit pada dua dataset, yaitu UCD database dan physionet database [14]. Tahapan berikutnya adalah praproses dengan tujuan untuk mengurangi gangguan derau. Derau dapat diperoleh dari berbagai sumber, di antaranya derau dari sumber listrik, derau dari peralatan medis, dan derau saat perekaman ECG akibat adanya gerakan atau kontraksi otot pasien. Derau tersebut dapat dikurangi dengan melakukan penapisan. Penapisan yang dilakukan menggunakan pendekatan Undecimated Wavelet Transform (UWT) sangat membantu mengurangi fluktuasi sinyal ECG-apnea [15]. Penelitian lainnya menggunakan pendekatan WA detrend dengan fungsi dekomposisi Daubechies 6 untuk menghilangkan derau baseline wander [16]. Selanjutnya adalah tahap ekstraksi fitur dengan tujuan mendapatkan nilai-nilai fitur sesuai dengan karakteristik sinyal ECG. Nilai fitur terdiri atas kumpulan vektor yang mewakili fitur-fitur yang dianalisis. Metode yang paling banyak digunakan untuk mengekstraksi informasi pada rekaman ECG adalah berdasarkan nilai fitur yang diperoleh dari Heart Rate Variability (HRV) pada domain waktu dan frekuensi [17]-[19]. Pada beberapa kasus, penelitian lainnya menggunakan karakteristik gelombang ECG untuk mendapatkan nilai fitur, seperti QRS morfologi dan amplitudo gelombang T [20], amplitudo gelombang S [21], dan amplitudo gelombang R [22], [23].
Keberhasilan suatu proses klasifikasi pada sinyal ECG sangat dipengaruhi oleh beberapa faktor, di antaranya akurasi metode dalam mendeteksi gelombang R. Pengaruh derau dan perubahan morfologi akibat kompleksitas rekaman ECG akan mempersulit penentuan posisi gelombang $\mathrm{R}$ secara tepat, bahkan pada beberapa kasus bentuk gelombang $\mathrm{R}$ tidak sempurna dan terbalik. Oleh karena itu, penelitian mengenai deteksi QRS kompleks akan sangat menentukan ketelitian proses perhitungan nilai variabel HRV. Salah satu penelitian dengan kinerja yang baik dalam mendeteksi QRS kompleks menggunakan kombinasi metode wavelet transform, Hilbert transform, dan adaptive thresholding [23]. Proses berikutnya adalah seleksi fitur. Proses seleksi ini bertujuan mendapatkan nilai fitur paling dominan di antara sekian banyak fitur yang didapat dan menghilangkan fitur-fitur yang tidak relevan dengan pola sinyal yang akan dianalisis. Tahapan terakhir adalah proses klasifikasi gangguan tidur menjadi dua kategori, yaitu apnea dan nonapnea.

Oleh karena itu, analisis sinyal ECG dengan banyak fitur menggunakan seleksi fitur ReliefF dan metode klasifikasi Adaptive Boosting (AdaBoost) diharapkan mampu meningkatkan kinerja klasifikasi dua kelas, yaitu apnea dan nonapnea. Selain itu, makalah ini diharapkan mampu mengatasi masalah dan kekurangan dari peralatan PSG, sehingga membantu memberikan pertimbangan dalam pengambilan keputusan medis melalui pengukuran, analisis, dan diagnosis pola sinyal ECG satu sadapan pada penderita gangguan tidur. Kontribusi dari penelitian ini adalah 1) pengembangan Home Sleep Care (HSC) untuk deteksi otomatis gangguan tidur menggunakan rekaman ECG satu sadapan; 2) penerapan metode seleksi fitur yang tepat yang mampu mengevaluasi fitur-fitur nonlinear dan tidak relevan berdasarkan HRV untuk mengurangi kompleksitas komputasi; dan 3) penerapan metode klasifikasi yang menghasilkan akurasi tinggi sehingga dapat menjadi bahan pertimbangan tenaga medis untuk menganalisis dan mengdiagnosis penderita gangguan tidur dan melakukan tindakan lanjutan yang diperlukan.

\section{Metodologi dan KaraKteristiK DatA}

Pada makalah ini, metode pendeteksian gangguan tidur secara otomatis diuraikan seperti pada Gbr. 1. Metode yang diusulkan terdiri atas dua tahap utama. Tahap pertama adalah mengidentifikasi dan mengurangi derau menggunakan WA detrend yang memanfaatkan kelebihan transformasi wavelet dalam setiap detail sinyal pada rekaman ECG satu sadapan. Sinyal ECG diekstraksi menggunakan metode analisis berdasarkan domain waktu, domain frekuensi, dan analisis nonlinear. Selanjutnya, fitur dominan dipilih berdasarkan proses seleksi menggunakan pendekatan algoritme ReliefF Pada tahap kedua, hasil klasifikasi didapat dengan pengujian dataset menggunakan teknik uji validasi $k$-fold cross validation dengan membagi menjadi 10 fold. Metode yang digunakan untuk proses klasifikasi adalah Support Vector Machine (SVM) sigmoid, SVM polinomial, SVM linear, SVM (Radial Basis Function) RBF, $k$-NN, Neural Network (NN), dan AdaBoost. 


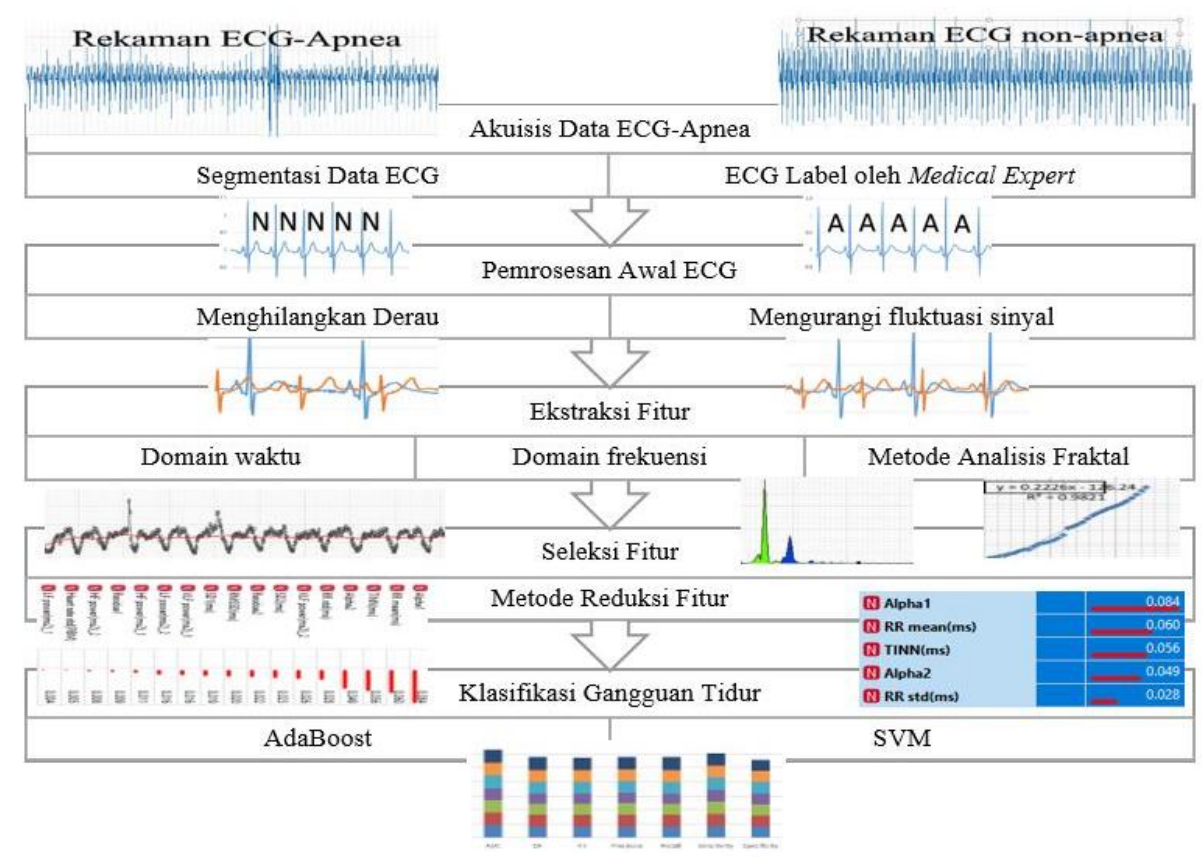

Gbr. 1 Diagram blok algoritme klasifikasi gangguan tidur.



(a)

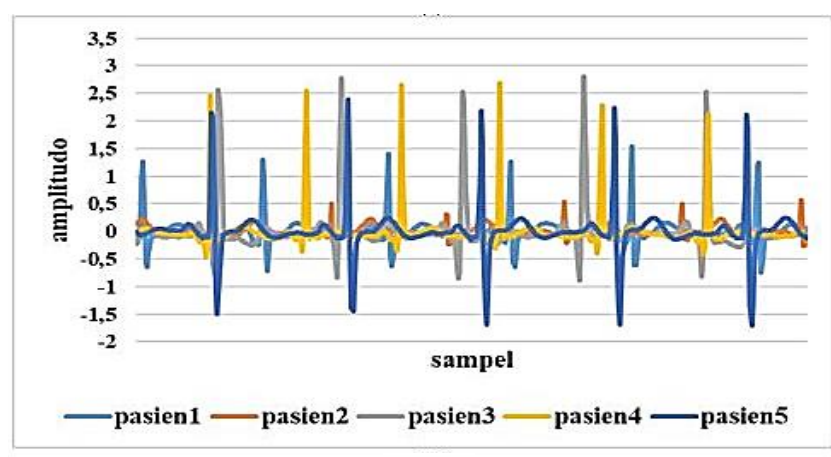

(b)

Gbr. 2 Representasi rekaman ECG-apnea dengan durasi 1 menit, (a) rekaman ECG nonapnea; (b) rekaman ECG apnea.

\section{A. Karakteristik Dataset ECG-Apnea}

Makalah ini menggunakan dataset yang bersumber dari physionet ECG-apnea database [24]. Data ECG diakuisisi pada frekuensi $100 \mathrm{~Hz}$ dengan resolusi 12 bit menggunakan satu

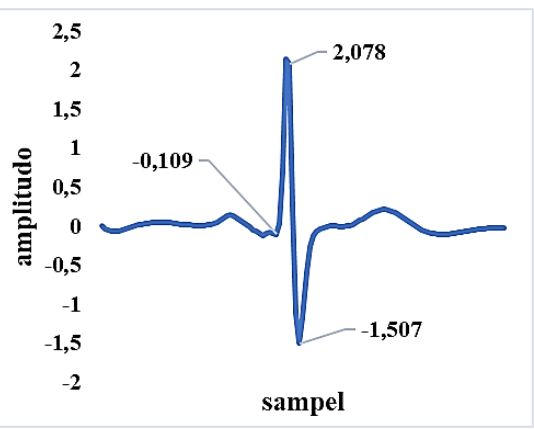

Gbr. 3 Detail gelombang P, QRS kompleks, dan gelombang T.

sadapan (lead II). Data ECG memiliki durasi antara 7 sampai 10 jam dan diberi indeks rekaman a01-a20, b01-b05, dan c01c10. Setiap rekaman sudah diberi label apnea (A) dan normal (N) setiap menitnya. Pemberian label ini dilakukan dokter spesialis sesuai dengan standar yang dikeluarkan oleh American Academy of Sleep Medicine [25]. Karakteristik data ECG yang digunakan untuk pengujian adalah 294 rekaman yang berdurasi \pm 16 menit dan memiliki tujuh belas fitur. Fiturfitur ini diperoleh dari proses ekstraksi menggunakan beberapa metode, di antaranya hasil perhitungan nilai variabel $R R$ interval antara satu puncak $\mathrm{R}$ dengan puncak $\mathrm{R}$ yang lain, metode Fast Fourier Transform (FFT), metode Autoregressive Spectral Analysis (ARSA), metode poincare plot, metode analisis nonlinear Detrended Fluctuation Analysis (DFA), dan perhitungan dari morfologi QRS kompleks. Gbr. 2(a) menujukkan hasil akuisisi data ECG-apnea untuk kategori nonapnea yang direkam pada lima pasien, sedangkan Gbr. 2(b) menunjukkan hasil akusisi data ECG-apnea untuk kategori apnea pada lima pasien. Rekaman ECG untuk setiap pasien memiliki morfologi yang sama, walaupun pada kasus tertentu bentuknya terbalik. Perbedaannya adalah adanya variasi tinggi 




(a)

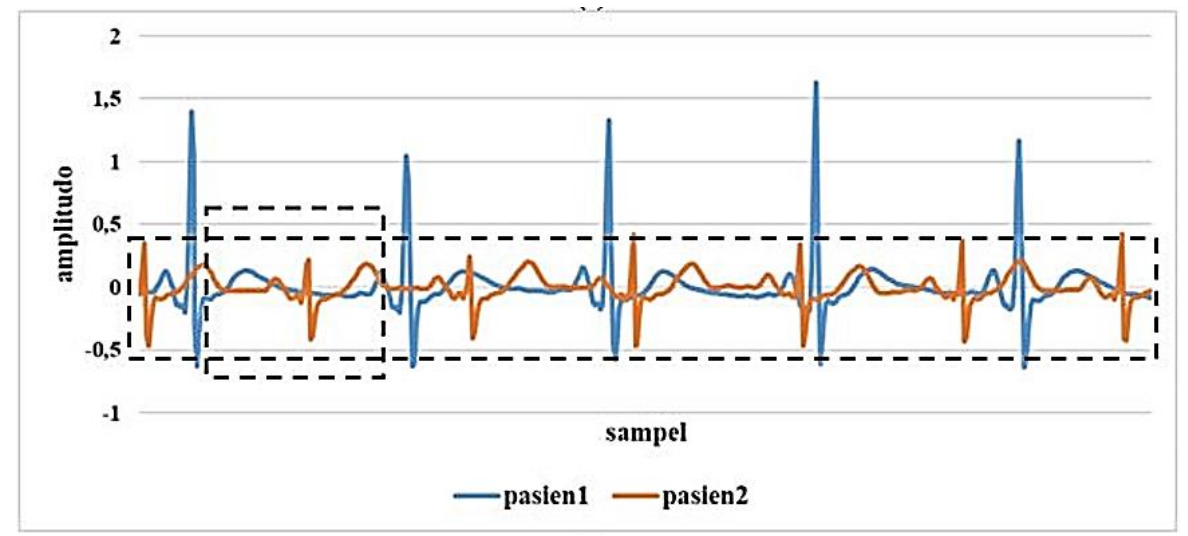

(b)

Gbr. 4 Rekaman ECG pasien1 dan pasien2, (a) sebelum praproses, (b) setelah praproses.

dan lebar amplitudonya serta sempit dan lebarnya area QRS kompleks.

\section{B. Praproses Rekaman ECG Satu Sadapan}

Praproses memiliki peran penting untuk mendapatkan akurasi yang tinggi dalam mendeteksi gelombang $\mathrm{R}$ tanpa dipengaruhi oleh berbagai macam derau. Secara matematis, sinyal ECG $y[n]$ didefinisikan dengan mengacu pada (1). Variabel $s[n]$ merupakan representasi sinyal ECG dan $w[n]$ merupakan nilai yang diperoleh dari keseluruhan derau yang menginterferens sinyal ECG, sedangkan $\alpha$ adalah parameter pelemahan sinyal.

$$
y[n]=\alpha s[n]+w[n] .
$$

Secara keseluruhan, QRS kompleks adalah gelombang yang bentuknya tidak berubah walaupun banyak derau yang memengaruhinya. Rentang frekuensi gelombang QRS antara 5 sampai $25 \mathrm{~Hz}$ [26], sedangkan gelombang lainnya memiliki rentang frekuensi di bawah rentang frekuensi gelombang QRS. Pada Gbr. 3 ditunjukkan sinyal ECG dengan morfologi lengkap, yaitu gelombang $\mathrm{P}, \mathrm{QRS}$, dan T.

Penelitian mengenai penapisan di antaranya menggunakan self-convolution window pada Hamming window pada puncak gelombang berukuran kecil dengan akurasi nilai kesalahan $0,117 \%$ [27]. Penelitian lainnya menggunakan teknik discrete wavelet transform untuk meningkatkan kualitas sinyal ECG dari pengaruh derau, sehingga meningkatkan akurasi deteksi QRS sebesar 99,71\% [28]. Penapisan pada makalah ini menggunakan UWT untuk mengurai derau dan menggunakan pendekatan skema WA detrend dengan pengaturan Daubechies pada level 6 untuk mengurangi baseline wander [29]. Gbr. 4(a) menunjukkan rekaman ECG asli dengan indikasi apnea sebelum dilakukan praproses, sedangkan Gbr. 4(b) menunjukkan rekaman ECG setelah praproses. Hasil rekaman ECG menunjukkan adanya perbaikan pada kualitas sinyal ECG, karena derau berkurang dan sinyal lebih stabil serta tidak berfluktuasi.

\section{Ekstraksi Fitur}

Pada bagian ini dijelaskan beberapa metode ekstraksi untuk mendapatkan nilai fitur pada rekaman ECG-apnea menggunakan beberapa pendekatan.

1) Analisis HRV Berdasarkan RR Interval: Perubahan pada nilai HRV menunjukkan adanya variasi waktu antara puncak gelombang pada sinyal ECG. Perubahan ini mengindikasikan adanya informasi klinis yang dapat diukur, dinterpretasikan, dan disesuaikan dengan standar pengukuran atau anotasi yang telah diverifikasi oleh tenaga medis atau dokter, sehingga mengurangi kesalahan diagnosis atau dalam membuat kesimpulan. HRV menjadi rujukan yang baku dalam men- 
jelaskan perbedaan antara puncak $\mathrm{R}$ yang berdekatan pada interval tertentu. Perbedaan tersebut di antaranya adalah variasi panjang gelombang, variasi $R R$ interval, variasi puncak gelombang $\mathrm{P}$, gelombang QRS, dan gelombang T.

2) Pengukuran HRV pada Domain Waktu: Perubahan yang terjadi pada aktivitas jantung secara langsung berpengaruh pada variasi amplitudo dan lebar pada QRS kompleks detak jantung. Selanjutnya, setiap perubahan pada detak jantung dapat diperoleh nilai kuantifikasinya untuk mengetahui infomasi klinis yang lebih mendalam saat diagnosis. Salah satu pendekatan kuantifikasi detak jantung dapat menggunakan domain waktu. Pendekatan ini menghasilkan rekaman interval gelombang $\mathrm{R}$ yang saling berdekatan untuk mengetahui rekaman ECG merupakan rekaman normal atau tidak normal. Di antara parameter pada domain waktu yang sering digunakan adalah $R R$ mean (milidetik), RR std (milidetik), heart rate (beat per menit), RMSSD (milidetik), dan TINN (milidetik) [30]. Selain itu, karakteristik QRS kompleks berupa beats, qrs amplitude mean, qrs amplitude standard deviation (std), qrs width mean, dan qrs width std.

3) Pengukuran HRV pada Domain Frekuensi: Pengukuran HRV dengan menganalisis variasi spektral merupakan pendekatan pada domain frekuensi. Power Spectral Density (PSD) adalah pengetahuan mendasar mengenai distribusi PSD sebagai fungsi frekuensi. FFT dan autoregressive transform (AR) adalah teknik yang digunakan untuk mengetahui karakteristik ECG berdasarkan spektum frekuensi pada setiap komponen frekuensi rendah dan frekuensi tinggi. Di antara spektral komponen frekuensi adalah Very Large Frequency (VLF), Large Frequency (LF), dan High Frequency (HF) [30].

4) Analisis Nonlinear: HRV yang tidak beraturan memiliki korelasi dengan variasi terhadap panjang gelombang yang dianalisis. Kompleksitas variabel elektrofisiologis menjadi informasi berharga untuk menginterpretasikan perilaku HRV. Di antara pendekatan yang digunakan untuk mengukur sifat invariant sinyal ECG pada durasi tertentu adalah pendekatan poincare plot, Lyapunov exponents, detrended fluctuation analysis, dan Kolmogonov entropy [30].

\section{Seleksi Fitur}

Seleksi fitur adalah teknik untuk mengurangi dimensi dari sekian banyak fitur yang akan digunakan. Pengurangan dimensi ini bertujuan menghilangkan bagian-bagian fitur yang tidak penting dan berulang pada sekumpulan fitur yang sangat besar. Oleh karena itu, untuk mendapatkan fitur-fitur yang memiliki peran penting dan berkaitan erat dengan karakteristik gangguan tidur, diperlukan teknik untuk menyeleksi fitur-fitur tersebut. Proses seleksi ini harus memperhatikan metode yang digunakan agar tidak menghilangkan informasi klinis yang akan sangat berpengaruh dalam mendiagnosis gangguan tidur. Pada makalah ini, dengan jumlah rekaman sebanyak 294 dan 17 fitur, diperlukan metode seleksi yang mampu menyeleksi sesuai dengan karakteristik sinyal gangguan tidur, baik untuk sinyal apnea maupun untuk sinyal nonapnea. Salah satu metode untuk seleksi fitur yang digunakan pada pengujian adalah ReliefF [31]. Metode ReliefF merupakan salah satu pendekatan yang cocok untuk klasifikasi dua kelas atau lebih. ReliefF juga sangat kuat dalam menangani invariant dataset dan dataset yang tidak lengkap. Perhitungan jarak antara kelas untuk menemukan tetangga terdekat dilakukan dengan menghitung jumlah total atas semua atribut berdasarkan Manhattan distance.

\section{E. Proses Klasifikasi Gangguan Tidur}

Proses klasifikasi pada makalah ini menggunakan beberapa metode, di antaranya metode klasifikasi SVM dengan empat tipe kernel, yaitu linear, polinomial, RBF, dan sigmoid. Metode lainnya yang diuji adalah $k-N N, \mathrm{NN}$, dan AdaBoost.

1) Metode Support Vector Machine (SVM): Proses klasifikasi menggunakan mesin pembelajaran SVM pada dasarnya adalah menggabungkan ruang fitur berdasarkan jenis kernel dan pengklasifikasiannya menggunakan pendekatan hyperplane. Sebuah hyperplane terbaik pada dasarnya memiliki perbedaan margin antara dua kelas yang diujikan. Ketepatan dalam pemilihan kernel akan menyebabkan terwakilinya data dalam ruang fitur, sehingga mengurangi risiko kesalahan dalam proses klasifikasi. Oleh karena dataset memiliki dua kelas, yaitu apnea dan nonapnea, maka pendekatan SVM dapat digunakan secara optimal untuk memisahkan kelas yang satu dengan kelas yang lainnya. Metode kernel melakukan pemetaan data dari input space ke feature space, sehingga penggunaan kernel memungkinkan pemisahan kelas dilakukan dengan sangat baik pada feature space, yang sebelumnya pada input space tidak dapat dilakukan pemisahan secara linear. Proses transformasi untuk data nonlinear menghasilkan beberapa jenis kernel, di antaranya adalah kernel linear yang mengacu pada (2), kernel polinomial yang mengacu pada (3), kernel RBF seperti pada (4), dan kernel sigmoid seperti ditunjukkan pada (5).

$$
\begin{gathered}
K(x, u)=x^{T} \cdot u \\
K(x, u)=\left(a x^{T} \cdot u+c\right)^{T}, q>0 \\
K(x, u)=\exp \left(-\frac{\|x-u\|^{2}}{\sigma^{2}}\right) \\
K(x, u)=\tanh \left(\beta x^{2} u+y\right)
\end{gathered}
$$

2) Metode Nonparametrik $k-N N$ : Metode $k-N N$ merupakan metode klasifikasi yang sederhana tetapi memiliki kemampuan yang sangat baik dalam beberapa kasus praktis. Metode $k-N N$ dengan kemampuannya tidak mensyaratkan sebaran data, baik sebaran normal maupun tidak normal. Sebaran data ini menjadi penting karena secara nyata seringkali ditemui adanya ketidakseimbangan dataset yang diuji, sehingga mengurangi kinerja metode klasifikasi. Pada kasus klasifikasi biasanya diukur kedekatan antar anggota kelompok dengan ukuran jarak terdekat atau distance function, di antaranya penghitungan jarak berdasarkan fungsi Euclidean (Euclidean distance) yang mengacu pada (6), Manhattan distance yang ditunjukkan pada (7), dan Minkowski distance seperti pada (8). Sementara itu, pada kasus yang lain, jika dataset memiliki data yang tidak linear, maka pendekatan Hamming distance, seperti pada (9), sangat diperlukan. 


$$
\begin{gathered}
d(y, x)=\sqrt{\sum_{i=1}^{k}\left(x_{i}-y_{i}\right)} \\
d(y, x)=\sum_{i=1}^{k}\left|x_{i}-y_{i}\right| \\
d(y, x)=\left(\sum_{i=1}^{k}\left(\left|x_{i}-y_{i}\right|\right)^{q}\right)^{1 / q} \\
\text { dan } \mathrm{x}=\mathrm{y} \Rightarrow \mathrm{d}=0 ; \mathrm{x} \neq \mathrm{y} \Rightarrow 1 \\
d_{H}=\sum_{i=1}^{k}\left|x_{i}-y_{i}\right|
\end{gathered}
$$

3) Metode Neural Network (NN): Penggunaan machine learning untuk klasifikasi sangat bergantung pada keberagaman pola yang akan diklasifikasikan. Untuk mendapatkan pola yang sesuai dengan dua kelas yang dikelompokkan, makalah ini menggunakan salah satu Artificial Neural Network (ANN) dengan arsitektur sederhana, yaitu mengunakan Multilayer Perceptron (MLP). MLP merupakan bagian dari feedforward ANN yang menggunakan fungsi aktivasi nonlinear. Secara umum, arsitektur ANN memiliki tiga lapisan, yaitu input layer, hidden layer, dan output layer. Input layer dinyatakan dalam vektor $\mathrm{P}$ dengan $\mathrm{L}$ baris, yang diekspresikan sebagai $p_{1}, p_{2}, \ldots, p_{R}$. Setiap input layer memiliki bobot $w_{1,1}$, $w_{2,1 \ldots}, w s_{1, L}$ dalam bentuk matrik $\mathrm{W}_{1}$, dengan $S_{1}$ adalah jumlah neuron.

4) Metode AdaBoost: AdaBoost bekerja berdasarkan teknik ensemble. Metode ensemble adalah sebuah teknik yang digunakan untuk mendapatkan model terbaik dengan cara menggabungkan beberapa metode yang memiliki model yang akurasinya rendah. Model AdaBoost merupakan pilihan terbaik untuk mengklasifikasikan dua kelas berdasarkan pendekatan decision tree. Oleh karena itu, pendekatan yang digunakan adalah model AdaBoostM1. Berikut ini tahapan-tahapan yang dilakukan oleh model AdaBoostM1.

1. AdaBoostM1 menandai setiap sampel dengan bobot (xi) yang sama, sehingga distribusinya seragam, dengan bobot awal $x i=1 / n ; n$ adalah jumlah sampel.

2. Selanjutnya, AdaBoostM1 memilih salah satu subset dari distribusi yang ada dan mengujinya menggunakan week learners (sebuah skema decision tree singkat dan sederhana), sehingga dihasilkan hipotesis $(h t)$.

3. Selanjutnya, $h t$ ini hanya terdiri atas dua kemungkinan output dari setiap input yang diterima, yaitu output +1 atau -1 untuk setiap kelas.

4. Menghitung error ( $\varepsilon t$ ) untuk setiap $h t$, dengan mengacu pada (10).

$$
\varepsilon t=\sum_{\left(i: h_{t}\left(x_{i}\right) \neq y_{i}\right)} D_{t}(i)
$$

5. Selanjutnya, dipilih $h t$ yang memiliki $\varepsilon t$ paling rendah, dengan syarat nilai $\varepsilon t$ harus kurang dari $1 / 2$, sehingga syaratnya mengacu pada (11).

$$
\beta_{t}=\varepsilon t /(1-\varepsilon t)
$$

6. Proses berikutnya adalah jika sampel terdeteksi benar, maka bobot sampel akan berkurang dan akan bertambah jika ada kesalahan klasifikasi.

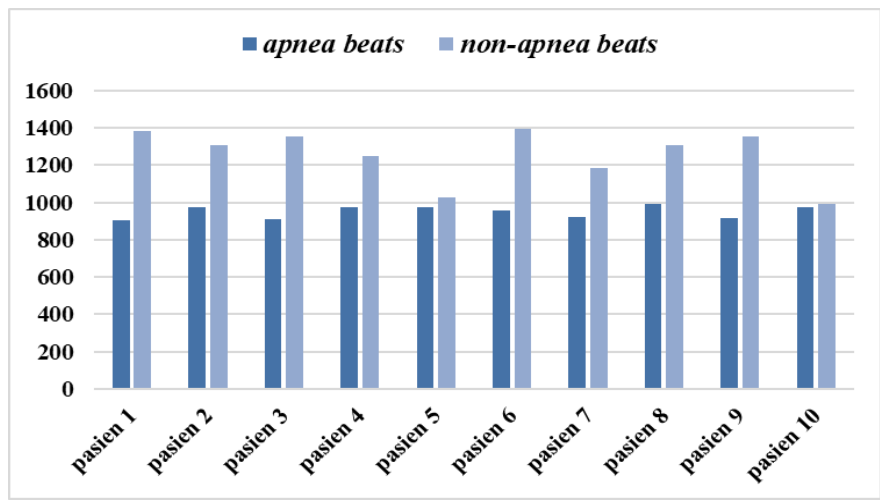

Gbr. 5 Sebaran beats berdasarkan HRV dengan indikasi apnea.

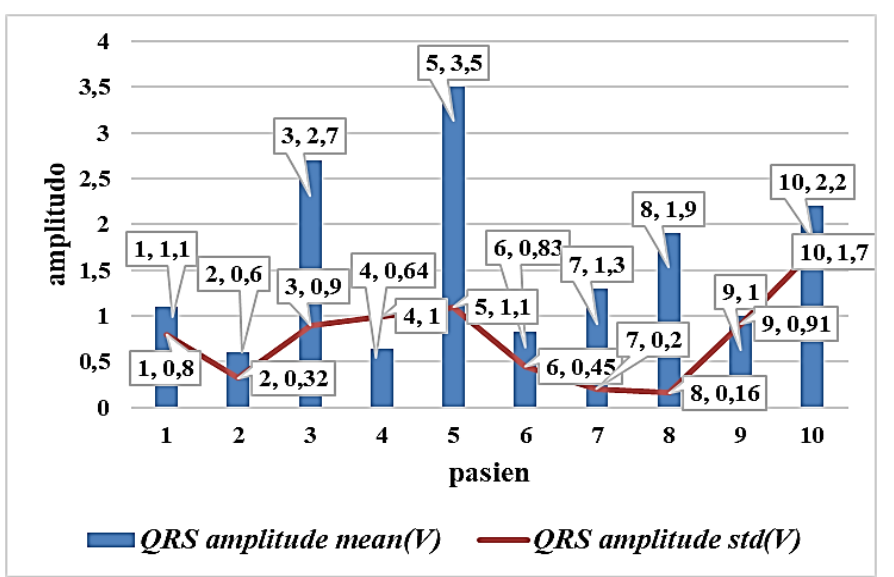

Gbr. 6 Sebaran QRS amplitude berdasarkan HRV dengan indikasi apnea.

7. Pada akhirnya, AdaBoostM1 memilih bobot paling besar dari beberapa pengklasifikasian dan merupakan keputusan terbaik yang dipilih.

\section{HASIL PENGUJIAN}

Hasil ekstraksi fitur pada sepuluh rekaman ECG dengan indikasi apnea akan diuraikan pada bagian ini. Nilai rerata fitur untuk karateristik QRS kompleks secara berurutan adalah untuk fitur beat sebesar 950,3, qrs amplitude mean sebesar 1,6, qrs amplitude standard deviation (std) sebesar 0,8, qrs width mean sebesar 99,3, dan qrs width std sebesar 58,4. Karakteristik morfologi QRS kompleks dengan sebaran beats ditunjukkan pada Gbr. 5, dengan nilai rerata dan standar deviasi sebesar 950,3 $\pm 31,9$.

Gbr. 6 menunjukkan sebaran amplitude mean untuk indikasi apnea dengan nilai bervariasi mulai dari $600 \mathrm{mV}$ sampai dengan $3.500 \mathrm{mV}$, dengan rerata dan standar deviasi adalah $1,6 \pm 1,0$. Dengan karakteristik tersebut, QRS kompleks dengan indikasi apnea memiliki sebaran amplitudo dengan distribusi normal karena nilai deviasinya mendekati nilai rerata. Sementara itu, Gbr. 7 merupakan sebaran QRS width mean dengan indikasi apnea memiliki rerata dan standar deviasi 99,3 $\pm 27,5$ dan sebaran $Q R S$ width std memiliki rerata dan standar deviasi 58,4 $\pm 23,9$.

Hasil pengujian pada sepuluh rekaman ECG dengan indikasi nonapnea menunjukkan perbedaan nilai fitur. Karakteristik QRS kompleks menunjukkan sebaran beats dengan rerata dan 


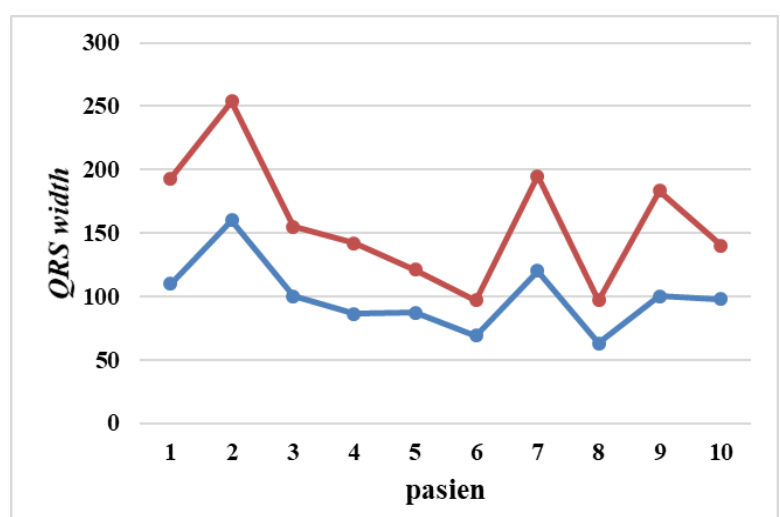

$\longrightarrow Q R S$ width mean(ms) $\rightarrow Q R S$ width std(ms)

Gbr. 7 Sebaran $Q R S$ width berdasarkan HRV dengan indikasi apnea.

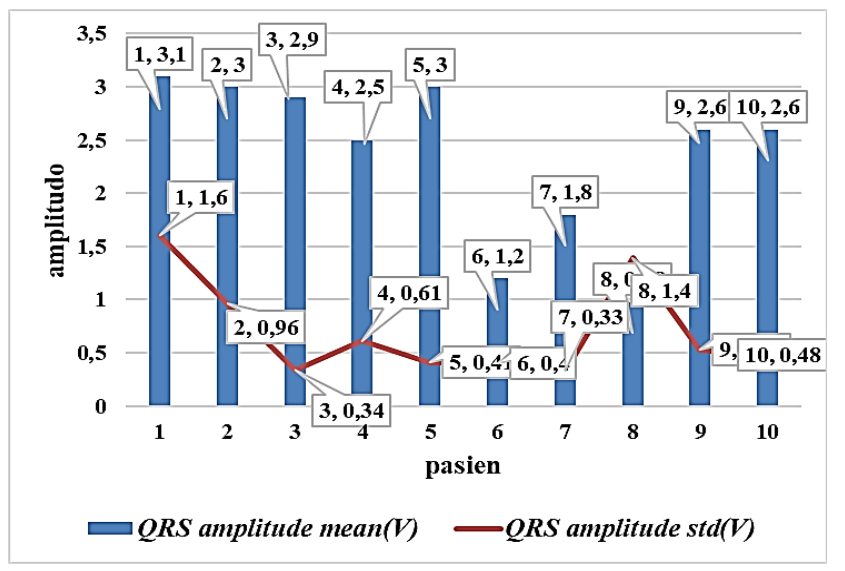

Gbr. 8 Sebaran QRS amplitude berdasarkan HRV dengan indikasi nonapnea.

standar deviasi $1.255,3 \pm 144,5$, seperti yang ditunjukkan pada Gbr. 5. Selain itu, rekaman ECG dengan indikasi nonapnea juga memiliki sebaran rerata dan standar deviasi berurutan, seperti QRS amplitude mean adalah 2,4 $\pm 0,8, Q R S$ amplitude std adalah

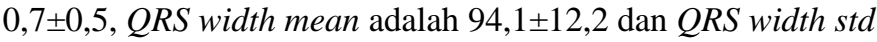
adalah 29,2 $\pm 4,5$. Gbr. 8 menunjukkan sebaran $Q R S$ amplitude mean untuk indikasi nonapnea dengan nilai bervariasi mulai dari $1.000 \mathrm{mV}$ sampai dengan $3.100 \mathrm{mV}$, dengan rerata dan standar deviasi adalah 2,4 $\pm 0,8$.

Sebaran QRS width mean dengan indikasi nonapnea memiliki rerata dan standar deviasi 94,1 12,2 dan sebaran $Q R S$

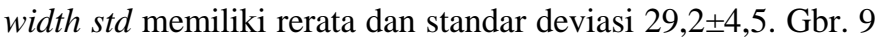
menunjukkan sebaran QRS width mean dengan indikasi nonapnea.

Hasil pengujian menunjukkan bahwa rekaman ECG dengan indikasi nonapnea memiliki karakteristik berbeda dibandingkan dengan rekaman ECG dengan indikasi apnea. Secara umum, fitur beats dan QRS amplitude mean rekaman ECG dengan indikasi nonapnea memiliki sebaran rerata nilai fitur lebih tinggi, sedangkan fitur $Q R S$ width mean-nya memiliki sebaran rerata lebih rendah.

\section{Pembahasan Hasil PEnguJian}

Pada bagian ini, dijelaskan temuan-temuan dan pembahasan saat dilakukan beberapa skenario untuk mendapatkan perkiraan

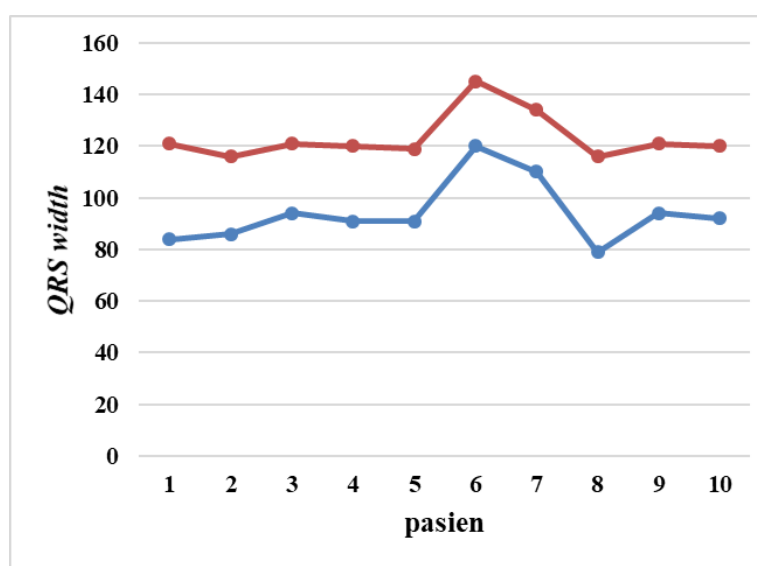

$\multimap Q R S$ width mean(ms) $\quad$ QRS width std(ms)

Gbr. 9 Sebaran $Q R S$ width berdasarkan HRV dengan indikasi nonapnea.

TABEL I

EVALUASI KINERJA METODE KLASIFIKASI

\begin{tabular}{|c|l|c|c|c|c|}
\hline No & Metode & TP & TN & FP & FN \\
\hline 1 & SVM linear & 105 & 122 & 40 & 27 \\
\hline 2 & SVM polinomial & 93 & 137 & 52 & 12 \\
\hline 3 & SVM RBF & 109 & 126 & 36 & 23 \\
\hline 4 & SVM sigmoid & 98 & 123 & 47 & 26 \\
\hline 5 & $k-N N$ & 115 & 106 & 30 & 43 \\
\hline 6 & NN & 112 & 125 & 33 & 24 \\
\hline 7 & AdaBoost & 126 & 139 & 19 & 10 \\
\hline
\end{tabular}

dan peningkatan akurasi pada beberapa metode klasifikasi. Sebanyak tujuh metode klasifikasi digunakan untuk mendapatkan akurasi terbaik dengan mengimplementasikan fitur-fitur yang sesuai dengan karakteristik sinyal ECG-apnea berdasarkan nilai fitur dominan yang terseleksi. Metode yang pertama diuji adalah metode SVM dengan beberapa kernel, yaitu kernel RBF, kernel sigmoid, kernel polinomial, dan kernel linear. Metode berikutnya adalah $k-N N$, NN, dan AdaBoost. Untuk mengetahui peningkatan kinerja pada masing-masing metode, digunakan beberapa parameter, yaitu area under the ROC Curve (AUC), Classification Accuracy (CA), F1 score, precision $(\mathrm{P})$, recall $(\mathrm{R})$, sensitivity $(\mathrm{Se})$, dan specificity $(\mathrm{Sp})$. Berdasarkan hasil pengujian, seperti pada Gbr. 10, tampak metode AdaBoost memiliki nilai kinerja paling tinggi untuk semua parameter, yaitu CA, F1 score, precision, recall, sensitivity, dan specificity secara berurutan adalah $90,1 \%$, $90,1 \%, 90,3 \%, 90,1 \%, 86,9 \%$, dan 93,3\%, sedangkan AUC dengan nilai tertinggi diperoleh metode $\mathrm{NN}$, yaitu 90,9\%. Hasil pengujian menunjukkan bahwa AdaBoost mampu menghasilkan kinerja yang optimal dibandingkan metode lainnya. Kemampuan tersebut salah satunya disebabkan karena metode ini melakukan koreksi hasil prediksi pada setiap proses pelatihan dan dilakukan berulang sampai diperoleh hasil yang paling tinggi.

Seperti yang ditunjukkan pada Tabel I, dengan akurasi sebesar 90,1\%, metode AdaBoost memiliki kemampuan mengklasifikasikan secara tepat sebanyak 265 rekaman dari keseluruhan 294 rekaman. Dengan kata lain, metode klasifikasi AdaBoost mampu secara tepat mendeteksi 126 rekaman apnea 


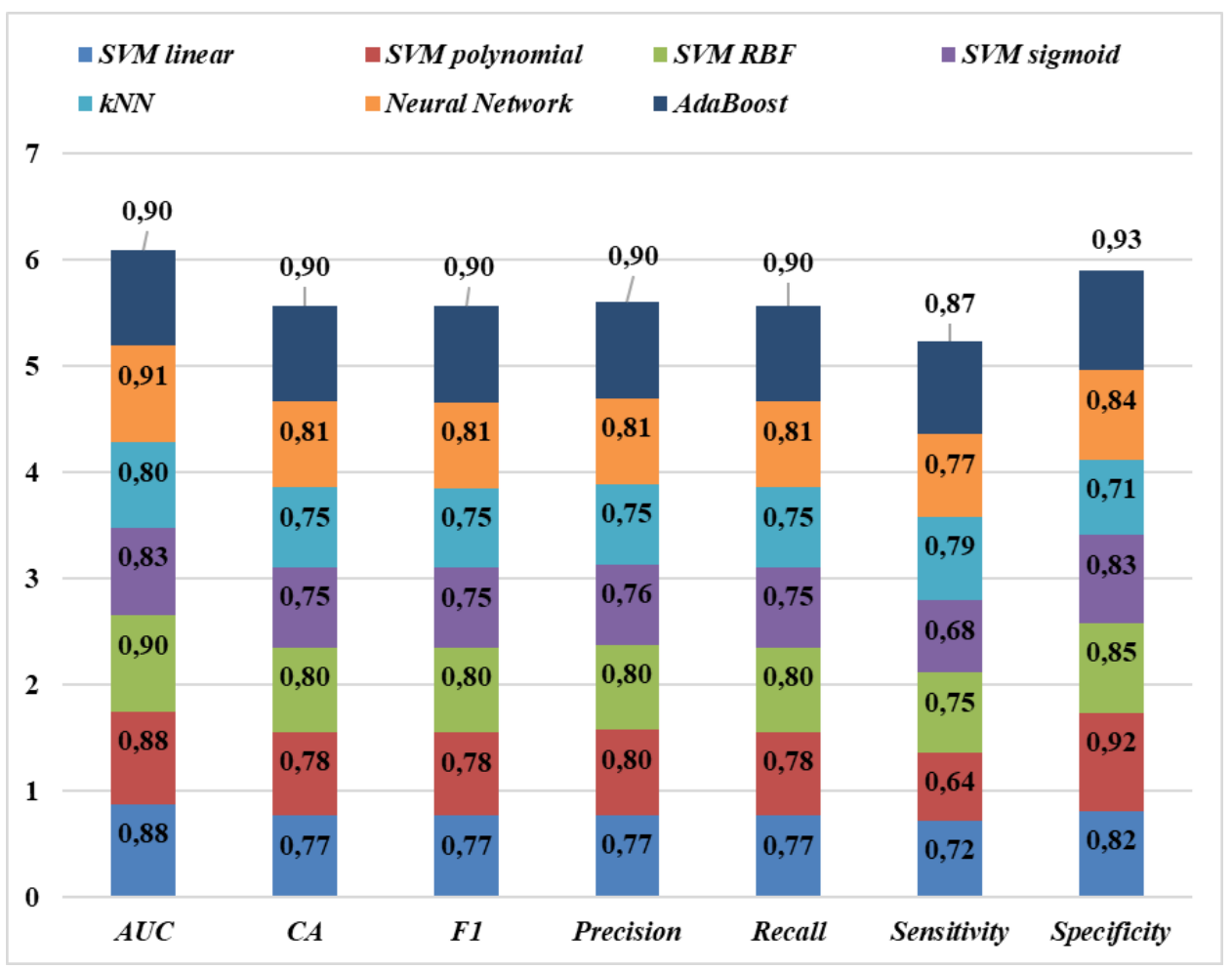

Gbr. 10 Ukuran kinerja beberapa metode klasifikasi.

dari keseluruhan 145 rekaman apnea dan mampu secara tepat mendeteksi 139 rekaman nonapnea dari keseluruhan 149 rekaman nonapnea. Metode AdaBoost juga memiliki ukuran sensitivitas yang tinggi, yaitu $86,9 \%$, dibandingkan dengan metode lainnya. Sensitivitas ini menunjukkan kemampuan metode mengklasifikasikan apnea secara tepat, yaitu dideteksi apnea sebanyak 126 rekaman (true positive rate/TP) dari 145 rekaman apnea. Selain itu, ukuran parameter specificity menunjukkan nilai yang sangat tinggi, yaitu sebesar 93,3\%. Hal ini menunjukkan bahwa metode ini memiliki kemampuan untuk mendeteksi 139 rekaman nonapnea secara tepat pada 149 rekaman nonapnea (true negative rate/TN).

Dari pengujian mesin pembelajaran SVM menggunakan empat kernel, hasil klasifikasi paling tinggi adalah SVM dengan kernel RBF, yakni sebesar 79,9\%. Ukuran kinerja akurasi ini menunjukkan bahwa SVM dengan kernel RBF mampu mengklasifikasikan 235 rekaman apnea dan nonapnea secara tepat dari total 294 rekaman. Kernel RBF mendeteksi 109 rekaman apnea dari keseluruhan 145 rekaman dan mendeteksi secara tepat 126 rekaman nonapnea dari keseluruhan 149 rekaman. Metode $k-N N$ memiliki kemampuan dengan kinerja prediksi dalam mendeteksi rekaman apnea sebanyak 115 dari keseluruhan 145 rekaman dan mendeteksi rekaman nonapnea sebanyak 106 dari keseluruhan 149 rekaman. Metode NN, yang memiliki AUC paling tinggi, mempunyai kinerja prediksi dalam mendeteksi rekaman apnea sebanyak 112 rekaman dari keseluruhan 145 rekaman, sedangkan kinerja prediksi deteksi rekaman nonapnea adalah sebanyak 125 rekaman dari 149 rekaman nonapnea. Nilai AUC yang tinggi ini menunjukkan kemampuan algoritme dalam mendeteksi rekaman apnea dan nonapnea secara tepat (true positive rate) sebanyak 237 rekaman dari total 294 rekaman yang diuji.

Berdasarkan pengujian, ada beberapa alasan yang menyebabkan Adaboost mampu menghasilkan akurasi lebih baik dibandingkan metode lain, di antaranya AdaBoost didesain untuk menyelesaikan kasus dengan dua kelas. AdaBoost bekerja berdasarkan skema decision tree dan melakukan pembobotan pada setiap pelatihan. Hasil prediksi yang salah diberi bobot yang lebih tinggi dan akan dimunculkan kembali dengan probabilitas yang lebih tinggi. Demikian seterusnya, sehingga diperoleh hasil akurasi yang lebih tinggi sebagai keputusan terbaik.

\section{KESIMPULAN}

Makalah ini bertujuan menghasilkan metode klasifikasi yang memiliki tingkat akurasi tinggi. Selain itu, melalui aplikasi berbasis teknologi kecerdasan buatan dan platform internet of things, setiap orang dapat merekam ECG dan hasilnya dikirim ke rumah sakit untuk dianalisis lebih mendalam oleh dokter sebagai bahan pertimbangan dalam pengambilan keputusan medis dan tindak lanjutnya. Berdasarkan evaluasi kinerja pada beberapa metode klasifikasi, dapat diketahui metode yang paling baik akurasinya. Dari uji validasi menggunakan teknik $k$-fold cross validation dengan 10 fold diperoleh akurasi paling baik adalah metode ensemble AdaBoost dengan akurasi 90,1\%, selanjutnya $k-N N$ sebesar 75,2\%, neural network sebesar $80,6 \%$, SVM dengan kernel linear dan SVM dengan kernel sigmoid masing-masing sebesar 77,2\% dan 75,2\%, SVM dengan kernel RBF sebesar 79,9\%, dan metode SVM dengan kernel polinomial memiliki akurasi paling rendah sebesar $78,2 \%$. Oleh 
karena itu, hasil penelitian ini akan sangat berguna sebagai dasar pengambilan keputusan bagi rumah sakit, fasilitas kesehatan tingkat pertama, dan dokter.

\section{UCAPAN TERIMA KASIH}

Terima kasih disampaikan kepada Kementrian Riset, Teknologi, dan Pendidikan Tinggi Republik Indonesia (Kemenristekdikti) atas dukungan dan bantuan melalui beasiswa Pendidikan Pascasarjana Dalam Negeri (BPPDN) dan Politeknik Negeri Batam atas dukungan dan kesempatan dalam tugas belajar.

\section{REFERENSI}

[1] D.W. Jung, S.H. Hwang, Y.J. Lee, D. Jeong, dan K.S. Park, “ApneaHypopnea Index Prediction Using Electrocardiogram Acquired During the Sleep-Onset Period," IEEE Transactions on Biomedical Engineering, Vol. 64, No. 2, hal. 295-301, Feb. 2017.

[2] V.A. Rossi, J.R. Stradling, dan M. Kohler, "Effects of Obstructive Sleep Apnoea on Heart Rhythm," European Respiratory Journal, Vol. 41, No. 2, hal. 1439-1451, Jun. 2013

[3] M.F. AkSahİn, B. Oltu, dan B.K. Karaca, "Sleep Apnea Detection Using Blood Pressure Signal," 2018 26th Signal Processing and Communications Applications Conference (SIU), 2018, hal. 1-4.

[4] M.S. Wise, D.L. Arand, R.R. Auger, S.N. Brooks, dan N.F. Watson, "Treatment of Narcolepsy and other Hypersomnias of Central Origin," Sleep, Vol. 30, No. 12, hal. 1712-1727, Des. 2007.

[5] D.W. Hudgel, "Sleep Apnea Severity Classification — Revisited," Sleep, Vol. 39, No. 5, hal. 1165-1166, Mei 2016.

[6] M. Singh, P. Liao, S. Kobah, D.N. Wijeysundera, C. Shapiro, dan F. Chung, "Proportion of Surgical Patients with Undiagnosed Obstructive Sleep Apnoea," British Journal of Anaesthesia, Vol. 110, No. 4, hal. 629636, Apr. 2013.

[7] M.K. Moridani, M. Heydar, dan S.S.J. Behnam, "A Reliable Algorithm Based on Combination of EMG, ECG and EEG Signals for Sleep Apnea Detection: (A Reliable Algorithm for Sleep Apnea Detection)," 2019 5th Conference on Knowledge Based Engineering and Innovation (KBEI), 2019, hal. 256-262.

[8] A.R. Hassan dan Md.A. Haque, "An Expert System for Automated Identification of Obstructive Sleep Apnea from Single-lead ECG Using Random Under Sampling Boosting," Neurocomputing, Vol. 235, hal 122-130, Apr. 2017.

[9] I. Fahruzi dan S. Hardiristanto, "Deteksi Kelainan Premature Atrial Contractions (PACS) berbasis Kombinasi Baseline Wander dan Transformasi Wavelet," Seminar Nasional Aplikasi Teknologi Informasi (SNATI), 2012, hal. C.1-C.5.

[10] E.S. Pane, A.D. Wibawa, dan M.H. Purnomo, "Improving the Accuracy of EEG Emotion Recognition by Combining Valence Lateralization and Ensemble Learning with Tuning Parameters," Cognitive Processing, Vol. 20, No. 4, hal. 405-417, Nov. 2019.

[11] W. Al-Salman, Y. Li, P. Wen, dan M. Diykh, “An Efficient Approach for EEG Sleep Spindles Detection Based on Fractal Dimension Coupled with Time Frequency Image," Biomedical Signal Processing and Control, Vol. 41, hal. 210-221, Mar. 2018.

[12] S. Suprijanto, A. Gareta R., F.K. Masyhuroh, dan S. Maisaroh, "Rancang Bangun Purwarupa Perangkat Wearable Headset untuk Pengukuran Sinyal Listrik pada Otak," Jurnal Nasional Teknik Elektro dan Teknologi Informasi (JNTETI), Vol. 7, No. 3, hal. 344-349, Sep. 2018.

[13] M. Deviaene, D. Testelmans, B. Buyse, P. Borzée, S.V. Huffel, dan C. Varon, "Automatic Screening of Sleep Apnea Patients Based on the $\mathrm{SpO} 2$ Signal," IEEE Journal of Biomedical and Health Informatics, Vol. 23, No. 2, hal. 607-617, Mar. 2019.

[14] A. Zarei dan B.M. Asl, "Automatic Detection of Obstructive Sleep Apnea Using Wavelet Transform and Entropy-Based Features from Single-Lead
ECG Signal," IEEE Journal of Biomedical and Health Informatics, Vol. 23, No. 3, hal. 1011-1021, Mei 2019.

[15] V.N.P. Raj dan T. Venkateswarlu, "ECG Signal Denoising Using Undecimated Wavelet Transform," 2011 3rd International Conference on Electronics Computer Technology, 2011, hal. 94-98.

[16] I. Fahruzi, I.K. Eddy Purnama, H. Takahashi, dan M.H. Purnomo, "Classification of Sleep Disorder from Single Lead Non-overlapping of ECG-Apnea based Non-Linear Analysis using Ensemble Approach," 2019 IEEE 10th International Conference on Awareness Science and Technology (iCAST), 2019, hal. 1-6.

[17] A.H. Khandoker, M. Palaniswami, dan C.K. Karmakar, "Support Vector Machines for Automated Recognition of Obstructive Sleep Apnea Syndrome from ECG Recordings," IEEE Transactions on Information Technology in Biomedicine, Vol. 13, No. 1, hal. 37-48, Jan. 2009.

[18] M. Bsoul, H. Minn, dan L. Tamil, "Apnea MedAssist: Real-time Sleep Apnea Monitor Using Single-Lead ECG," IEEE Transactions on Information Technology in Biomedicine, Vol. 15, No. 3, hal. 416-427, Mei 2011.

[19] C. Varon, A. Caicedo, D. Testelmans, B. Buyse, dan S.V. Huffel, "A Novel Algorithm for the Automatic Detection of Sleep Apnea from Single-Lead ECG," IEEE Transactions on Biomedical Engineering, Vol. 62, No. 9, hal. 2269-2278, Sep. 2015.

[20] T. Penzel, J. McNames, P. de Chazal, B. Raymond, A. Murray, dan G. Moody, "Systematic Comparison of Different Algorithms for Apnoea Detection Based on Electrocardiogram Recordings," Medical and Biological Engineering and Computing, Vol. 40, No. 4, hal. 402-407, Jul. 2002.

[21] J.N. McNames dan A.M. Fraser, "Obstructive Sleep Apnea Classification Based on Spectrogram Patterns in the Electrocardiogram," Computers in Cardiology 2000. Vol.27 (Cat. 00CH37163), 2000, hal. 749-752.

[22] P. de Chazal, C. Heneghan, E. Sheridan, R. Reilly, P. Nolan, dan M. O'Malley, "Automatic Classification of Sleep Apnea Epochs Using the Electrocardiogram," Computers in Cardiology 2000. Vol.27 (Cat. OOCH37163), 2000, hal. 745-748.

[23] P. Sabherwal, M. Agrawal, dan L. Singh, "Automatic Detection of the R Peaks in Single-Lead ECG Signal," Circuits, Systems, and Signal Processing, Vol. 36, No. 11, hal. 4637-4652, Nov. 2017.

[24] T. Penzel, G.B. Moody, R.G. Mark, A.L. Goldberger, dan J.H. Peter, "The Apnea-ECG Database," Computers in Cardiology 2000. Vol.27 (Cat. 00CH37163), 2000, hal. 255-258.

[25] V.K. Kapur, D.H. Auckley, S. Chowdhuri, D.C. Kuhlmann, R. Mehra, K Ramar, dan C.G. Harrod, "Clinical Practice Guideline for Diagnostic Testing for Adult Obstructive Sleep Apnea: An American Academy of Sleep Medicine Clinical Practice Guideline," Journal of Clinical Sleep Medicine, Vol. 13, No. 3, hal. 479-504, Mar. 2017.

[26] M. Elgendi, B. Eskofier, S. Dokos, dan D. Abbott, "Revisiting QRS Detection Methodologies for Portable, Wearable, Battery-Operated, and Wireless ECG Systems," PLoS ONE, Vol. 9, No. 1, hal. e84018, Jan. 2014.

[27] A. Kaur, A. Agarwal, R. Agarwal, dan S. Kumar, "A Novel Approach to ECG R-Peak Detection," Arabian Journal for Science and Engineering, Vol. 44, No. 8, hal. 6679-6691, Okt. 2018.

[28] S. Sahoo, P. Biswal, T. Das, dan S. Sabut, "De-noising of ECG Signal and QRS Detection Using Hilbert Transform and Adaptive Thresholding," Procedia Technology, Vol. 25, hal. 68-75, 2016.

[29] I. Fahruzi, I.K.E. Purnama, dan M.H. Purnomo, "An Investigation of Dynamic Features Influence in ECG-Apnea Using Detrended Fluctuation Analysis," 2018 International Conference on Intelligent Autonomous Systems (ICoIAS), 2018, hal. 23-27.

[30] F. Shaffer dan J.P. Ginsberg, "An Overview of Heart Rate Variability Metrics and Norms," Frontiers in Public Health, Vol. 5, hal. 1-17, Sep. 2017.

[31] M. Robnik-Šikonja dan I. Kononenko, "Theoretical and Empirical Analysis of ReliefF and RReliefF," Machine Learning, Vol. 53, No. 1, hal. 23-69, Okt. 2003. 